\title{
Carbon Fluxes and Export in the Northern and Middle Adriatic Sea Measured with Drifting Sediment Traps
}

J.- C. Miquel, S. Fowler, T. Hamilton, J. P. Heilmann, J. La Rosa, M. Carroll

This article was submitted to In: Ecosystems Research Report No. 32, The Adriatic Sea Proceedings of the workshop Physical and Biogeochemical Processes in the Adriatic Sea

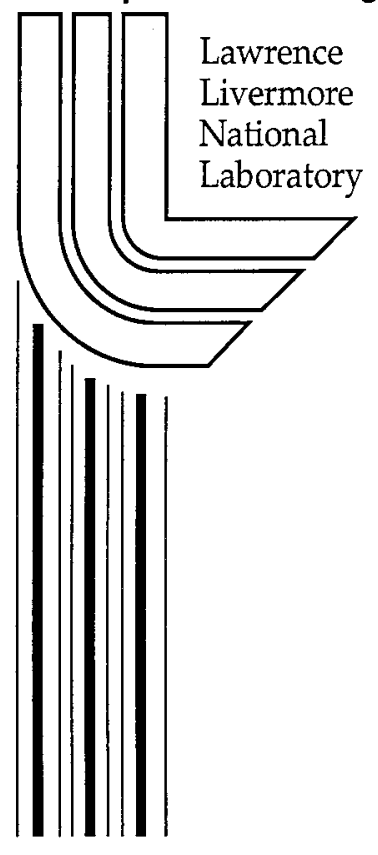
Ancona, Italy

April 23 through April 27, 1996

July 26, 2000 


\section{DISCLAIMER}

This document was prepared as an account of work sponsored by an agency of the United States Government. Neither the United States Government nor the University of California nor any of their employees, makes any warranty, express or implied, or assumes any legal liability or responsibility for the accuracy, completeness, or usefulness of any information, apparatus, product, or process disclosed, or represents that its use would not infringe privately owned rights. Reference herein to any specific commercial product, process, or service by trade name, trademark, manufacturer, or otherwise, does not necessarily constitute or imply its endorsement, recommendation, or favoring by the United States Government or the University of California. The views and opinions of authors expressed herein do not necessarily state or reflect those of the United States Government or the University of California, and shall not be used for advertising or product endorsement purposes.

This is a preprint of a paper intended for publication in a journal or proceedings. Since changes may be made before publication, this preprint is made available with the understanding that it will not be cited or reproduced without the permission of the author. 
European Commission

\section{Ecosystems research report No 32 THE ADRIATIC SEA}

Proceedings of the workshop

'Physical and biogeochemical processes in the Adriatic Sea'

Portonovo (Ancona), Italy

23 to 27 April 1996

Editors:

T. S. Hopkins,

A. Artegiani, G. Cauwet, D. Degobbis, A. Malej

Secretariat: R. M. Landotti

Local organiser

CNR-Istituto di Ricerca sulla Pesca Marittima (IRPEM)

Directorate-General for Research 


\title{
CARBON FLUXES AND EXPORT IN THE NORTHERN AND MIDDLE ADRIATIC SEA MEASURED WITH DRIFTING SEDIMENT TRAPS
}

\author{
Miquel J.-C. ${ }^{1}$, S. Fowler ${ }^{1}$, T. Hamilton ${ }^{1,3}$, J.P. Heilmann ${ }^{2}$, J. La Rosa ${ }^{1}$ and M. Carroll ${ }^{1}$ \\ ${ }^{2}$ Marine Environment Laboratory, LAEA, Principality of Monaco \\ ${ }^{2}$ Department of Marine and Coastal Ecology, DIFMAR, Charlottenlund, Danemark \\ ${ }^{3}$ Present address: HEAD, Lawrence Livermore National Laboratory, Livermore, USA
}

\begin{abstract}
In July 1993 and June 1995 drifting sediment traps were deployed near the Po outflow, in the coastal zone and in the Jabuka Pit in order to obtain quantitative information on the vertical flux of particulate material and export of organic carbon in the Northern and Middle Adriatic Sea. During these periods and in July 1994, the standing stock of carbon and nitrogen in the water column were also estimated. Carbon and nitrogen concentrations were higher in the north, with a mean of $266 \mu \mathrm{g} \mathrm{C} \mathrm{I}^{-1}$ in surface waters as compared to $92 \mu \mathrm{g} \mathrm{Cl}^{-1}$ in Middle Adriatic; maximum concentrations were associated to the less-saline surface-subsurface waters in the north and to the chlorophyll $a$ maximum in the Middle Adriatic. Organic carbon flux was roughly five times higher near the Po than in the more oligotrophic waters of the central region, with overall values ( 0.8 to $11.5 \mathrm{mg} \mathrm{m}^{-2} \mathrm{~d}^{-1}$ ) being low compared to the open Northwestern Mediterranean. Comparison with primary production measurements yielded estimates of carbon export ( $f$-ratio) of 4.7 and $3.4 \%$ in the Po and Pit stations, respectively, in 1993 and of 1.6 and $3.6 \%$ in the central part of the Adriatic in 1995 . These consistently low values suggest enhanced carbon recycling in the upper water column, even in regions characterized by different production and organic flux regimes. Zooplankton fecal pellets were important conveyors of organic carbon in this region; particularly those produced by fishes in the North and coastal sites."
\end{abstract}

Key words: Adriatic, sediment traps, carbon flux

\section{Introduction}

In order to assess the Northern Adriatic Sea's susceptibility to eutrophication one of the primary objectives of ELNA (EC/Environment Program, Eutrophic Limits of the Northern Adriatic) was to construct a complete carbon budget for the region. Any budget of this type requires quantitative data on the sinking flux of particulate carbon. Data on vertical mass and carbon fluxes in the Adriatic Sea are mostly derived from shallow-water studies with particle interceptors moored only a few meters above the sea floor and indicate very high mass fluxes on the order of several $\mathrm{g} \mathrm{m}^{-2} \mathrm{~d}^{-1}$ (Boldrin and Rabitti, 1992; Puskaric et al., 1992). Even if this magnitude of flux may be typical of Northern Adriatic coastal waters (Kovac et al., 1992), no data have previously been reported on vertical fluxes in the more open waters of the Adriatic.

Here we report results from two separate cruises during which we measured short-term (24-30 hours) carbon fluxes and other major components of downward fluxes (e.g., nitrogen, zooplankton fecal material) using drifting sediment traps at four open water stations in the Northern and Middle Adriatic. Both sediment trap experiments encompassed the June-July period, and the data have allowed assessment of the differences in vertical carbon flux between regions of high and low carbon concentrations in the water and high and low primary productivity. Longer-term (months) time-series observation on particle fluxes in open waters was not possible due to repeated interference related to commercial fishery activity in the Middle and Northern Adriatic. 


\section{Materials and methods}

In July 1993 and June 1995, downward fluxes of particulate material, carbon and associated elements were sampled using sediment traps. In July 1993, a drifting array including a single trap was deployed for two 24 -hour periods in Jabuka Pit $\left(42^{\circ} 52.3 \mathrm{~N}, 14^{\circ} 50.4 \mathrm{E}\right)$ and the Po river plume $\left(44^{\circ} 56.1 \mathrm{~N}, 13^{\circ} 01.1 \mathrm{E}\right)$ areas during the ELNA 3 cruise on board the R/V URANIA (Fig.1). The sediment trap used was a PPS-5 Technicap model with a conical collection jar and a $1 \mathrm{~m}^{2}$ surface opening fitted with a honeycomb baffle. The trap was positioned below the euphotic layer at $100-\mathrm{m}$ depth over the Jabuka Pit, and at $27 \mathrm{~m}$ over a seabed of 35-m depth east of the Po Delta. In June 1995, the drifting array included two traps and was deployed at two stations in the Middle Adriatic during a special trap cruise on board the R/V S. LO BIANCO (Fig. 1). The sediment traps were a PPS-3 Technicap model, cylindro-conical in shape with a surface opening of $0.125 \mathrm{~m}^{2}$. These traps sampled for 30 hours in the Jabuka Pit $\left(42^{\circ} 53.2 \mathrm{~N}, 14^{\circ} 43.8 \mathrm{E}\right)$ and 25 hours at another station adjacent to the Italian coast near the Giovanna oil platform $\left(42^{\circ} 45.6 \mathrm{~N}, 14^{\circ} 24.4 \mathrm{E}\right)$. At Jabuka Pit, traps were deployed at 100 and $180 \mathrm{~m}$ depth over a bottom of $260 \mathrm{~m}$; near the Giovanna platform; the traps were at 50 and $75 \mathrm{~m}$ over a bottom of $106 \mathrm{~m}$. During the 1995 cruise, the arrays drifted at a speed of $5.2 \mathrm{~km}$ per $24 \mathrm{~h}$ in a south-southeast direction at Jabuka Pit and $6.5 \mathrm{~km}$ per day in a northerly direction at the coastal station. Surface currents at both stations are normally oriented south-southeast in June-July and have an average speed of $30 \mathrm{~cm} \mathrm{~s}^{-1}$. Unfortunately, the Po site could not be visited in 1995 and thus, only the single 1993 flux data set is available from the Po Delta area in the Northern Adriatic.

Specific characteristics of sediment traps, particularly the size and shape, may influence their collection efficiency but preliminary results from an inter-comparison exercise (Heussner, pers. comm.) indicate similar trapping capabilities for both models used in this study. Individual collection cups of the traps were filled with a $2 \%$ buffered formaldehyde solution before deployment to prevent microbial degradation and grazing by swimmers. Following recovery, the sediment trap samples were refrigerated at $4^{\circ} \mathrm{C}$ before laboratory processing. Before desalting and drying, trap samples were inspected qualitatively, swimmers were manually removed under a dissecting microscope, and dominant biota were identified and their total dry weight measured. Fecal pellets were enumerated and measured using a binocular microscope connected to a computerized digital table. Fecal pellet organic carbon was estimated using calculated pellet volumes, measured densities and the dry-weight:carbon ratios of natural pellets obtained from shipboard zooplankton incubations (Miquel et al., 1995; Carroll et al., in press).

Due to the small quantity of material collected by the traps, samples were removed by filtration on pre-combusted and pre-weighed fiberglass filters (Whatman GF/F); the filters were then used to measure the mass fluxes and the elemental composition of the particles. These analyses required all the sample material; therefore no other analyses such as pigments, trace metals and pollutants could be performed.

Suspended particles were sampled near the drifting array at each site using Niskin water bottles fitted to a Seabird CTD. Vertical profiles of temperature, salinity, fluorometry and transmissivity were also measured. Samples were obtained from 7 to 19 discrete depths from the surface down to nearbottom depending on the bottom depth. For the analyses of total suspended matter (TSM), total and particulate organic carbon (POC), nitrogen (PON) and chlorophyll $a, 1$ to 51 of seawater were filtered on fiberglass filters Whatman GF/F. Filters were pre-weighed for TSM measurements and also precombusted for PON, total $\mathrm{C}$ and POC determinations. In addition to trap stations, suspended particles were sampled at 13 other sites during the ELNA 3 cruise (July 1993), a moored trap cruise (October 1993) and the ELNA 6 cruise (July 1994) to study north-south trends in particle composition.

Particulate carbon and nitrogen were determined with a CHN-Element Analyser (Heraeus). Total particulate carbon, particulate organic carbon (POC) and nitrogen (PON) were analysed for both the trap and water samples. Carbonate was removed from the POC samples prior to combustion with $1 \mathrm{M}$ phosphoric acid (Cauwet, 1975). Particulate inorganic carbon (PIC) contents were calculated from weight differences between total and organic carbon. The quality of total carbon, organic carbon and nitrogen measurements has been verified in an international inter-comparison exercise on sediment trap 
material and marine sediments (King et al., in press). Chlorophyll a concentrations were measured spectrophotometrically in $90 \%$ acetone extracts using the formulas of Jeffey and Humphrey (1975).

\section{Results and discussion}

Water column. The four stations sampled during trap deployments in 1993 and 1995 presented a well-stratified water column. The northernmost station, which most influenced by freshwater outflow from the Po river, was characterized by high temperature and low salinity waters in the upper 14 meters and was associated with high chlorophyll concentrations (Fig. 2a). The vertical chlorophyll profile was complex with variable surface biomasses and high biomass in deeper waters. Chlorophyll $a$ concentrations ranged from 0.1 to $0.5 \mu \mathrm{g} \mathrm{l}^{-1}$ and were the lowest at $10 \mathrm{~m}$ depth. The Jabuka Pit station in July 1993 displayed a strong thermocline at $24 \mathrm{~m}$ and a classical open ocean deep-surface maximum of fluorescence and chlorophyll $a$ with a maximum of $0.5 \mu \mathrm{g} \mathrm{l}^{-1}$ at 50-60 m depth. A second increase occurred at about $100 \mathrm{~m}$ with $0.13 \mu \mathrm{g}$ chlorophyll $a \mathrm{l}^{-1}$ (Fig. 2a). In June 1995 surface waters were colder and the thermocline shallower and not as well defined as in July 1993. Nevertheless, there was a clear chlorophyil $a$ peak at $60 \mathrm{~m}$ (Fig. 2b). Closer to the Italian coast in the vicinity of the Giovanna Platform, the stratification was weaker and there was a deep layer of less saline water at $50-60 \mathrm{~m}$ associated with a broad chlorophyll $a$ maximum and a slightly deeper increase in suspended particle load (Fig. 2b). Particle concentrations exceeded $1000 \mu \mathrm{g}^{\mathrm{dry} \mathrm{l}^{-1}}$ at $60-70 \mathrm{~m}$ in a nepheloid zone which was distinguished from the bottom layer with waters containing $300 \mu \mathrm{g}$ dry TSM ${ }^{-1}$.

Carbon and nitrogen concentrations in the water column were always higher in 1993 in the northern station, regardless of the depth, except for $\mathrm{N}$ at $50 \mathrm{~m}$ in the Jabuka Pit (Fig. 2a). Furthermore, the vertical profiles in the northern site were substantially different than those in the Middle Adriatic. At the Po outflow station, the highest concentrations were observed in the low salinity surface waters (438 $\mu \mathrm{g} \mathrm{C} \mathrm{l}^{-1}$ and 43-60 $\mu \mathrm{g} \mathrm{N} \mathrm{I}^{-1}$ ). In contrast, the maximum $\mathrm{C}$ and $\mathrm{N}$ at the Jabuka Pit site was associated with the chlorophyll $a$ maximum at $50-60 \mathrm{~m}$ depth (71 to $76 \mu \mathrm{g} \mathrm{Cl}^{-1}$ and $31 \mu \mathrm{g} \mathrm{N} \mathrm{I}^{-1}$ ). Thus, the highest concentrations of $\mathrm{C}$ and $\mathrm{N}$ were clearly related to phytoplankton biomass. Integrated POC and PON values for the water column at both sites were $4.1 \mathrm{~g} \mathrm{C} \mathrm{m}^{-2}$ and $0.9 \mathrm{~g} \mathrm{~N} \mathrm{~m}^{-2}$ (0-27 m, Po site), and $5.5 \mathrm{~g} \mathrm{C} \mathrm{m}^{-2}$ and $1.2 \mathrm{~g} \mathrm{~N} \mathrm{~m}^{-2}(0-100 \mathrm{~m}$, Jabuka Pit site), respectively. In 1995, the highest concentrations of $\mathrm{C}$ and $\mathrm{N}$ at the Jabuka Pit were also related to the phytoplankton peak at $60 \mathrm{~m}$ ( $265 \mu \mathrm{g} \mathrm{C}^{-1}$ and $26 \mu \mathrm{g} \mathrm{N}^{-1}$ ) but no distinct peaks were observed at the station closer to the shore (Giovanna site, Fig. 2b). Integrated values in June 1995 were substantially greater than in July 1993 for POC but similar for PON (see Table 5).

During another cruise in July 1994 (ELNA 6), a more intensive survey of the water column showed that $C$ and $N$ concentrations and vertical profiles observed in 1993 and 1995 were a consistent feature in the Northern Adriatic during summer; i.e. $\mathrm{C}$ and $\mathrm{N}$ concentrations higher in the north irrespective of depth, maximum concentrations in surface-subsurface waters in the north and at the chlorophyll $a$ maximum in the Middle Adriatic. The north-south decrease in concentrations can be seen, for example, in the carbon content in surface waters (upper $8 \mathrm{~m}$ ) of all stations sampled during 1993-1995 (Fig. 3). In stations located north of latitude $44^{\circ} 00^{\prime} \mathrm{N}$ the mean surface particulate carbon concentration was $266 \mu \mathrm{g} \mathrm{Cl}^{-1}$ (range: 134-712 $\mu \mathrm{g} \mathrm{C}^{-1}$ ) compared to only $92 \mu \mathrm{g} \mathrm{Cl}^{-1}$ (range: $38-148 \mu \mathrm{g} \mathrm{C}^{-1}$ ) for stations located in the Middle Adriatic south of $43^{\circ} 00^{\prime} \mathrm{N}$.

Carbon concentrations measured in the North and Middle Italian coast are much higher than those measured in summer in the open NW Mediterranean off the Gulf of Lions, but the former are in the range of concentrations encountered in coastal and sub-coastal areas where the fertilizing role of riverine inputs is maximal (Cauwet et al., 1997).

Vertical fluxes. Particle flux and organic carbon flux near the mouth of the Po were roughly 13 and 4.6 times higher, respectively, than values measured at approximately the same time in the oligotrophic waters over the Jabuka Pit (Table 1). Furthermore, the physical characteristics of sinking particles were quite different at the two sites. At the Po outflow, the particulate material was characterised by a large amount of amorphous, mucoid marine floc that contained many small zooplankton fecal pellets. In contrast, the 1993 sample from the Jabuka Pit was translucent and contained few fecal pellets and 
detrital particles. These observations suggest strong differences in productivity and food-web between the two regions, and probably result, at least in part, from the increased particle load in the waters under the influence of the Po.

The particle flux data from the Jabuka Pit in June 1995, showed similar mass and organic carbon fluxes through $100 \mathrm{~m}$ depth as measured earlier, suggesting that low carbon flux may be a general feature during late spring - early summer in the Middle Adriatic (Table 1). On two consecutive days that measurements were made, organic carbon flux through $180 \mathrm{~m}$ ranged from 46 to $54 \%$ of that leaving the top $100 \mathrm{~m}$. This observation indicates that considerable degradation and/or recycling of carbon was taking place as the particles sank through the water column. This is typical of what has been reported for open ocean locations (e.g., Martin et al., 1987; Miquel et al., 1994).

At the shallower coastal site near the AGIP Giovanna oil platform, the patterns of particle fluxes were somewhat different. The fluxes, while of the same order of magnitude as in the Jabuka Pit, were higher at depth (Table 1). The two-fold higher mass flux at $75 \mathrm{~m}$ could be attributed to the presence of a nepheloid layer observed by CTD profiles (see Fig. 2b). However, the significant increase in organic carbon and nitrogen fluxes between 50 and $75 \mathrm{~m}$ (Table 1) and the increase in POC and N content of the settling particles (Table 2) suggest that the higher flux closer to the bottom is also the result of pelagic production associated with the fluorescence maximum recorded at $60-70 \mathrm{~m}$ depth.

Elemental composition of particles also suggests strong influences by the Po outflow at the northern station. Whereas organic carbon accounted for $24 \%$ of the dry mass of the sinking particles from the Jabuka Pit, off the Po the organic carbon contribution was only $9 \%$ (Table 2). In contrast, inorganic carbon was relatively higher in particulate matter from the Po ( $2.4 \%$ dry wt.) compared to the Jabuka Pit sample $(0.9 \%$ dry wt.). It is also noteworthy that in the oligotrophic waters of the Jabuka Pit, the radiolarian flux, although not significant in numbers (42 individuals $\mathrm{m}^{-2} \mathrm{~d}^{-1}$ ), represented nearly $5 \%$ of the mass flux and was certainly an important contributor to the biogenic silica flux. Near the Po outflow, large fish fecal pellets contributed significantly to the downward mass and carbon flux. Despite their numerical paucity ( 36 pellets $\mathrm{m}^{-2} \mathrm{~d}^{-1}$ ) they accounted for approximately $30 \%$ of mass flux and $60 \%$ of carbon flux because of their large size (mean length $3 \mathrm{~mm}$, diameter $1.5 \mathrm{~mm}$ ). If the fish pellets are not considered, then the remaining zooplankton fecal pellets represented only 6 to $10 \%$ of the carbon flux at both sites (Tables 3 and 4). Trap samples from both stations sampled in 1995 were also enumerated for different types of fecal pellets and the results are set out in Table 3. Numerical pellet fluxes generally ranged from $10^{2}$ to $10^{3} \mathrm{~m}^{-2} \mathrm{~d}^{-1}$. At the Jabuka Pit station, pellets were dominated by the spherical and elliptical types, which are typical of copepods and other mesozooplankton. A large component of cylindrical pellets in the $180 \mathrm{~m}$ trap suggests a substantial contribution from euphausiids. The carbon flux via fecal pellets was 25 to $45 \%$ of the total carbon flux at that depth and less than $16 \%$ in the $100 \mathrm{~m}$ trap (Table 4). The fraction of cylindrical pellets was much lower at the nearshore Giovanna site, although the relative proportions of the remaining pellet types was similar to that in the Jabuka Pit. As for the Po Station in 1993, fish pellets contributed very significantly to the total carbon flux in these coastal waters. In general, the presence of numerous fecal pellets at these stations underscores the importance of zooplankton grazing activities in effecting the flux of primary carbon in this region.

In addition to fecal pellet characterisation, the particulate samples were examined for other components. Swimmers made up a substantial fraction of the particulates and among those, a large number of larval bivalves were noted in samples collected near the Giovanna platform. At $50 \mathrm{~m}$ larval bivalve fluxes were as high as $2500 \mathrm{~m}^{-2} \mathrm{~d}^{-1}$. At somewhat greater depth $(75 \mathrm{~m})$, fluxes decreased to roughly $100 \mathrm{~m}^{-2} \mathrm{~d}^{-1}$. The larval bivalves from the family Limidae (Sabelli, pers. comm.) appeared to be nearly oval with a mean diameter of $245 \mu \mathrm{m}$.

Removal of particulate carbon and nitrogen from the water column by sedimentation below the euphotic layer represents generally a very small fraction of the standing stock, normally less than $1 \%$, and increases from oligotrophic to eutrophic environments (Peinert and Miquel, 1994). Assuming steady-state conditions, the losses via sedimentation of particulate organic carbon and nitrogen in Middle Adriatic (Jabuka and Giovanna stations) were only 0.02 to $0.05 \% \mathrm{~d}^{-1}$ of the organic carbon pool and 0.03 to $0.05 \% \mathrm{~d}^{-1}$ of the nitrogen standing stock in the water above the traps (Table 5), indicating that there was virtually no removal from surface waters. Fluxes off the Po, although much higher, were 
not particularly high for a coastal environment. Sinking particulate carbon represented $0.28 \% \mathrm{~d}^{-1}$ of the organic carbon stock in the water column and nitrogen loss was $0.18 \% \mathrm{~d}^{-1}$. The measured losses in summer 1993 and 1995 suggest that at the Jabuka Pit there was a much higher recycling efficiency and that the site was oligotrophic, whereas the northern part of the Adriatic was mesotrophic to eutrophic.

During the 1993 drifting trap experiments in the Jabuka Pit and near the Po River outflow, primary production was measured by the ${ }^{14} \mathrm{C}$ method (Heilmann, 1998) in order to estimate the fraction of the autochtonous organic carbon which was exported from the euphotic zone ( $f$ ratio) in these two regions. For June 1995, primary production was derived from fluorescence profiles and chlorophyll $a$ data, combined to field measurements carried out in summer 1993 and 1994 . In the North, primary production was broadly 2 to 3 times higher than in Middle Adriatic (Jabuka Pit and a coastal station) and the fraction of it exported from the euphotic zone was $4.7 \%$ (Table 6). In Middle Adriatic, differences in primary production (double in June as compared to July) were not reflected in downward POC export. These relatively low $f$-ratios $(<5 \%)$ are typical of what might be expected in oligotrophic regions of the ocean and strongly suggest enhanced carbon recycling in the upper water column at that time of the year. To our knowledge, these are the first measurements of carbon export coupled with productivity data in the Adriatic and, thus, it is difficult to draw general conclusions about intensive recycling of carbon either spatially or temporally in this region. Our finding of low carbon export, particularly for the northern station, is surprising in that the more eutrophic situation there usually results in a much higher fraction of carbon exported from the water column (Eppley \& Peterson, 1979). Nevertheless, our findings are based on a single short-term measurement in that area, and long-term measurements may reveal a different pattern. In both cases, the majority of the primary production results from cells $>8 \mu \mathrm{m}$ in diameter. According to Heilmann (1998), such a situation in coastal waters should hold the potential for a greater vertical export of organic carbon, however, this was not in evidence from the sediment trap measurements. Clearly, more data on carbon export in the different regions and over longer periods of time are needed before we can assess the general degree of carbon recycling in the upper water column.

Comparison of mass and POC fluxes in the Adriatic to those measured at the DYFAMED timeseries station in the Ligurian Sea, NW Mediterranean (Miquel et al., 1995) clearly indicates that, despite higher carbon content in the waters of the Adriatic, downward fluxes in summer were less important there than in the open Mediterranean. In fact, the average mass and POC fluxes in open waters during the oligotrophic period of June-July at $200 \mathrm{~m}$ depth from 1987 through 1991 were $90 \mathrm{mg} \mathrm{m}^{-2} \mathrm{~d}^{-1}$ and $17 \mathrm{mg} \mathrm{C} \mathrm{m}^{-2} \mathrm{~d}^{-1}$, respectively (Miquel et al., ibid.). Thus, carbon fluxes in summer were consistently lower in the Adriatic and only mass fluxes in the northern part were comparable to open Mediterranean data.

Data on vertical mass and carbon flux in the Adriatic Sea are few and thus, it is difficult with the limited amount of data reported from this study, to draw major conclusions on general trends of flux in this region. Most existing information is derived from coastal studies which indicate very high mass fluxes, i.e. of the order of several $\mathrm{g} \mathrm{m}^{-2} \mathrm{~d}^{-1}$; however, as reported by Puskaric et al. (1992), such high fluxes appear to be associated primarily with resuspended sediments, at least for the period November to April. Neither our nearshore data nor results from the open Middle Adriatic are in agreement with previous observations of very high mass fluxes in the Adriatic; in fact, results from our sediment trap studies indicate far lower fluxes on the order of several tens of milligrams $\mathrm{m}^{-2} \mathrm{~d}^{-1}$ in the Northern and Middle Adriatic.

\section{Conclusion}

Floating sediment traps were used successfully to obtain data sets on flux and carbon export in two contrasting areas of the Adriatic during summer. Although organic carbon flux was roughly five times higher off the Po Delta in the northern sector than that measured in the Jabuka Pit and along the central coast of the Adriatic, fluxes were low at both sites suggesting an enhanced carbon recycling in the upper water column. Carbon export estimates ( $f$-ratio) also support the hypothesis of higher recycling of carbon in the water column. Besides demonstrating how mesotrophic-eutrophic and oligotrophic 
systems can affect the downward flux of organic carbon in the Adriatic, these experiments also produced the first data on vertical carbon fluxes from the euphotic zone of the Middle Adriatic. This conclusion based on sediment trap data confirm the suggestion of Faganeli et al. (1994) that a greater part of the autocthonous marine particulate organic matter in the Adriatic is degraded in the water column.

\section{Acknowledgments}

This work was carried out under a subcontract to So.Pro.Mar. Spa within the frame of the ELNA Project, EC/Environment Program, contract No. EV5V-CT92-0225. We thank So.Pro.Mar. Spa and CNR-IRPeM (Ancona) for providing ship time and logistic support. The IAEA Marine Environment Laboratory operates under an agreement between the International Atomic Energy Agency and the Government of the Principality of Monaco.

\section{References}

Boldrin A. and S. Rabitti, 1992. Suspended matter in the Gulf of Venice (Northern Adriatic Sea): years 1990-1991. Rapp. Comm. int. Mer Médit. 33: 322

Carroll M. L., J.-C. Miquel and S.W. Fowler (in press). Seasonal patterns and depth-specific trends of zooplankton fecal pellet fluxes in the northwestern Mediterranean Sea. Deep Sea Research

Cauwet G., 1975. Optimisation d'une technique de dosage du carbone organique des sediments. Chemical Geology 16: 59-63

Cauwet G., A. Miller, S. Brasse, G. Fengler, R.F.C. Mantura and A. Spitzy, 1997. Dissolved and particulate organic carbon in the western Mediterranean Sea. Deep Sea Research 44: 769-779

Eppley R.W. and B.J. Peterson, 1979. Particulate organic matter flux and planktonic new production in the deep ocean. Nature 282: 677-680

Faganeli J., J. Pezdic, B. Ogorelec, M. Misic and M. Najdek, 1994. The origin of sedimentary organic matter in the Adriatic. Cont. Shelf Res. 14(4): 365-384

Heilmann J.P. and K. Richardson, 1998. Phytoplankton distribution and activity in the Northern Adriatic Sea. In: T.S. Hopkins, A. Artegiani, G. Cauwet, D. Degobbis, A. Malej (Eds.). Ecosystems Research No. 32. The Adriatic Sea (EUR 18834), Environment and Climate RTD Programme of the European Commission. This volume

Jeffrey S.W. and G.F. Humphrey, 1975. New spectrophotometric equations for determining chlorophylls $\mathrm{a}, \mathrm{b}, \mathrm{c}_{1}$ and $\mathrm{c}_{2}$ in higher plants, algae and natural phytoplankton. Biochem. Physiol. Pflanzen 167: 191-194

King P., H. Kennedy, P.P.Newton, T.D. Jickells, T. Brand, S. Calvert, G. Cauwet, H. Etcheber, B. Head, A. Khripounoff, B. Manighetti and J.-C. Miquel. In press. Analysis of total and organic carbon and total nitrogen in sediment trap material and marine sediment: an interlaboratory comparison. Mar. Chem.

Kovac N., J. Faganeli and J. Pezdic, 1992. Sources and fluxes of suspended particulate matter in shallow coastal waters (Gulf of Trieste, Northern Adriatic). Rapp. Comm. int Mer Médit. 33: 381

Martin J.H., G.A. Knauer, D.M. Karl and W.W. Broenkow, 1987. VERTEX: Carbon cycling in the northeast Pacific. Deep-Sea Res. 34(2): 267-285

Miquel J.-C., S.W. Fowler, J. La Rosa and P. Buat-Ménard, P., 1994. Dynamics of the downward flux of particles and carbon in the open northwestern Mediterranean Sea. Deep-Sea Res. 41(2): 243-261

Miquel J.-C., S.W. Fowler, B. Mostajir and L. La Rosa, 1995. Long term study of particulate carbon flux in the open NW Mediterranean Sea. In: S. Tsunogai, K. Iseki, I. Koike and T. Oba, (Eds.). Global Fluxes of Carbon and its Related Susbtances in the Coastal Sea-Ocean-Atmosphere System. Proceedings of the 1994 Sapporo IGBP Symposium, 14-17 November 1994, Hokkaido University, Sapporo, Hokkaido, Japan, M\&J International, Yokohama, 353-359 
Peinert R. and J.-C. Miquel, 1994. The significance of frontal processes for vertical particle fluxes: a case study in the Alboran Sea (SW Mediterranean Sea). J. Mar. Systems, 5, 377-389

Puskaric S., S.W. Fowler and J.-C. Miquel, 1992. Temporal changes in particulate flux in the Northern Adriatic Sea. Estuar. Coast. Shelf Sci. 35(3): 267-287

This work was performed under the auspices of the U.S. Department of Energy by the University of California, Lawrence Livermore National Laboratory under Contract No. W-7405-Eng-48. 
Table 1 Vertical flux of particles, carbon and nitrogen in the Northern and Middle Adriatic during summer 1993 and 1995

\begin{tabular}{|c|c|c|c|c|c|c|c|c|}
\hline $4 \%$ & \%or & 1) & \%.\% & א. & 6.8\% & W\%or & \%6\% & \%.6. \\
\hline Po outflow & $\begin{array}{l}44^{\circ} 56.1 \mathrm{~N} \\
13^{\circ} 01.1 \mathrm{E}\end{array}$ & 24 July ' 93 & 27 & 35 & 127 & 14.6 & 11.5 & 1.6 \\
\hline Jabuka Pit & $\begin{array}{l}42^{\circ} 52.3 \mathrm{~N} \\
14^{\circ} 50.4 \mathrm{E}\end{array}$ & 14 July ' 93 & 100 & 242 & 10.1 & 2.6 & 2.5 & 0.3 \\
\hline Jabuka Pit & $\begin{array}{l}42^{\circ} 53.2 \mathrm{~N} \\
14^{\circ} 43.8 \mathrm{E}\end{array}$ & $\begin{array}{c}9 \text { June '95 } \\
10 \text { June ‘ } 95 \\
9 \text { June ' } 95 \\
10 \text { June ‘ } 95\end{array}$ & $\begin{array}{l}100 \\
100 \\
180 \\
180\end{array}$ & $\begin{array}{l}260 \\
260 \\
260 \\
260\end{array}$ & $\begin{array}{c}7.6 \\
10.2 \\
3.4 \\
7.4\end{array}$ & $\begin{array}{l}2.9 \\
3.3 \\
0.8 \\
1.6\end{array}$ & $\begin{array}{l}1.7 \\
2.9 \\
0.8 \\
1.5\end{array}$ & $\begin{array}{l}0.6 \\
0.5 \\
0.1 \\
0.2\end{array}$ \\
\hline $\begin{array}{c}\text { Central coast } \\
\text { (near } \\
\text { Giovanna } \\
\text { Platform) }\end{array}$ & $\begin{array}{l}42^{\circ} 45.6 \mathrm{~N} \\
14^{\circ} 24.4 \mathrm{E}\end{array}$ & $\begin{array}{l}11 \text { June '95 } \\
11 \text { June ' } 95\end{array}$ & $\begin{array}{l}50 \\
75\end{array}$ & $\begin{array}{l}106 \\
106\end{array}$ & $\begin{array}{c}5.2 \\
12.0\end{array}$ & $\begin{array}{l}1.4 \\
3.8\end{array}$ & $\begin{array}{l}1.4 \\
3.5\end{array}$ & $\begin{array}{l}0.2 \\
0.6\end{array}$ \\
\hline
\end{tabular}


Table 2 Elemental composition of sedimenting particles collected in the traps

\begin{tabular}{|c|c|c|c|c|c|}
\hline 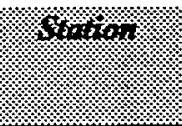 & $13 \%$ & 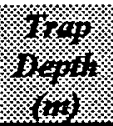 & 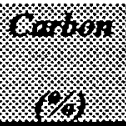 & $n_{6}^{6}$ & wim \\
\hline Po outflow & 24 July ' 93 & 27 & 11.5 & 9.1 & 1.3 \\
\hline $\begin{array}{c}\text { Jabuka Pit } \\
\text { (1993) }\end{array}$ & 14 July '93 & 100 & 25.3 & 24.4 & 2.5 \\
\hline Jabuka Pit & 9 June '95 & 100 & 37.6 & 22.1 & 7.5 \\
\hline \multirow[t]{3}{*}{ (1995) } & 10 June ' 95 & 100 & 32.1 & 28.1 & 5.2 \\
\hline & 9 June '95 & 180 & 23.2 & 22.2 & 3.4 \\
\hline & 10 June '95 & 180 & 21.9 & 20.9 & 3.1 \\
\hline \multirow{2}{*}{$\begin{array}{c}\text { Central } \\
\text { coast }\end{array}$} & 11 June '95 & 50 & 26.7 & 25.9 & 3.8 \\
\hline & 11 June '95 & 75 & 31.7 & 29.3 & 4.9 \\
\hline
\end{tabular}


Table 3 Flux of different types of fecal pellets in the Northern and Middle Adriatic during summer 1993 and 1995, and their relative contribution to the total pellet flux (in \%, in brackets)

\begin{tabular}{|c|c|c|c|c|c|c|c|c|}
\hline 6ron & 16\% & (3) & $\%$ & $\%$ & $\% \% \%=\%$ & \% & $\% \%$ & 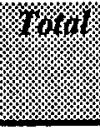 \\
\hline Po outflow & 24 July '93 & 27 & $32(\sim 0 \%)$ & $28080(76 \%)$ & $8640(23 \%)$ & $36(\sim 0 \%)$ & $1(\sim 0 \%)$ & 36789 \\
\hline $\begin{array}{c}\text { Jabuka Pit } \\
\text { (1993) }\end{array}$ & 14 July '93 & 100 & $16(1 \%)$ & $440(27 \%)$ & $1160(72 \%)$ & - & - & 1616 \\
\hline \multirow{4}{*}{$\begin{array}{c}\text { Jabuka Pit } \\
\text { (1995) }\end{array}$} & 9 June ' 95 & 100 & $36(5 \%)$ & $394(51 \%)$ & $243(32 \%)$ & $59(8 \%)$ & $36(5 \%)$ & 768 \\
\hline & 10 June '95 & 100 & $56(6 \%)$ & $508(52 \%)$ & $316(32 \%)$ & $56(6 \%)$ & $48(5 \%)$ & 984 \\
\hline & 9 June '95 & 180 & $154(9 \%)$ & $770(44 \%)$ & $742(42 \%)$ & $34(2 \%)$ & $64(4 \%)$ & 1764 \\
\hline & 10 June ' 95 & 180 & $\begin{array}{c}360 \\
(18 \%)\end{array}$ & $864(43 \%)$ & $720(36 \%)$ & $24(1 \%)$ & $28(1 \%)$ & 1996 \\
\hline \multirow{2}{*}{$\begin{array}{c}\text { Central } \\
\text { coast }\end{array}$} & 11 June '95 & 50 & $14(2 \%)$ & $299(47 \%)$ & $326(51 \%)$ & - & - & 639 \\
\hline & 11 June ‘95 & 75 & $24(4 \%)$ & $284(53 \%)$ & $197(37 \%)$ & $26(5 \%)$ & $6(1 \%)$ & 537 \\
\hline
\end{tabular}


Table 4 Fecal pellet carbon fluxes and their contribution to total carbon export $(w=$ calculations with fish fecal pellets; $w / 0=$ calculations without fish fecal pellets $)$

\begin{tabular}{|c|c|c|c|c|c|c|}
\hline \multirow[t]{2}{*}{$1 \% 10$} & \multirow[t]{2}{*}{83} & \multirow[t]{2}{*}{ 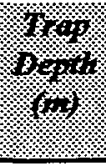 } & \multicolumn{2}{|c|}{ 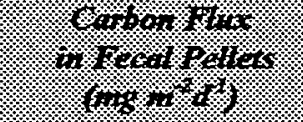 } & \multicolumn{2}{|c|}{ 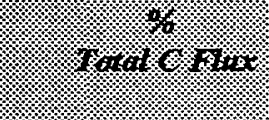 } \\
\hline & & & xy & $4 \%$ & 4 & 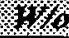 \\
\hline Po outflow & 24 July '93 & 27 & 8.95 & 0.94 & 61.4 & 6.4 \\
\hline $\begin{array}{c}\text { Jabuka Pit } \\
\text { (1993) }\end{array}$ & 14 July '93 & 100 & 0.25 & 0.25 & 9.7 & 9.7 \\
\hline Jabuka Pit & 9 June ‘ 95 & 100 & 0.17 & 0.10 & 5.9 & 3.6 \\
\hline (1995) & 10 June '95 & 100 & 0.52 & 0.26 & 15.9 & 7.8 \\
\hline & 9 June '95 & 180 & 0.20 & 0.18 & 25.0 & 22.2 \\
\hline & 10 June 995 & 180 & 0.67 & 0.64 & 44.9 & 42.6 \\
\hline Central coast & 11 June 95 & 50 & 0.02 & 0.02 & 1.3 & 1.3 \\
\hline & 11 June '95 & 75 & 2.87 & 0.06 & 75.7 & 1.5 \\
\hline
\end{tabular}

Table 5 Integrals of suspended particulate organic carbon (POC) and nitrogen (PON) in the waters above the traps and losses via sedimentation (as \% per day). Only traps located below the maximum chlorophyll $a$ depth are considered

\begin{tabular}{|c|c|c|c|c|c|c|}
\hline Sirntion & Bowe & 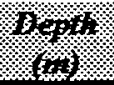 & 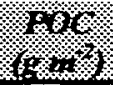 & V. & . & 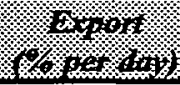 \\
\hline Po outflow & 24 July '93 & 27 & 4.1 & 0.28 & 0.9 & 0.18 \\
\hline $\begin{array}{c}\text { Jabuka Püt } \\
\text { (1993) }\end{array}$ & 14 July '93 & 100 & 5.5 & 0.05 & 1.2 & 0.03 \\
\hline $\begin{array}{c}\text { Jabuka Pit } \\
\text { (1995) }\end{array}$ & 9 June '95 & 100 & 12.5 & 0.02 & 1.6 & 0.03 \\
\hline Central coast & 11 June '95 & 75 & 9.6 & 0.04 & 1.2 & 0.05 \\
\hline
\end{tabular}


Table 6 Comparison of primary production in the water column above the traps (total and by cell size fraction) with particulate organic carbon exported from the euphotic zone at locations in the Middle and Northern Adriatic during the cruise ELNA 3, July 1993, and ELNA-Trap, June 1995. Only traps located below the maximum chlorophyll $a$ depth are considered

\begin{tabular}{|c|c|c|c|c|c|c|}
\hline 817601 & 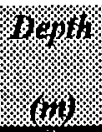 & 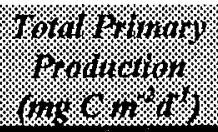 & 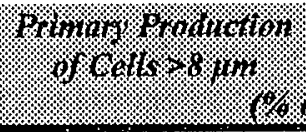 & 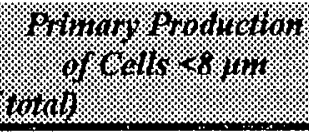 & 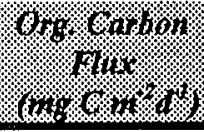 & 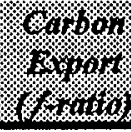 \\
\hline Po outflow & 27 & 246 & 91 & 9 & 11.5 & 4.7 \\
\hline $\begin{array}{c}\text { Jabuka Pit } \\
\text { (1993) }\end{array}$ & 100 & 74 & 72 & 28 & 2.5 & 3.4 \\
\hline $\begin{array}{c}\text { Jabuka Pit } \\
\text { (1995) }\end{array}$ & 100 & 142 & - & - & 2.3 & 1.6 \\
\hline Central Coast & 75 & 96 & - & - & 3.5 & 3.6 \\
\hline
\end{tabular}




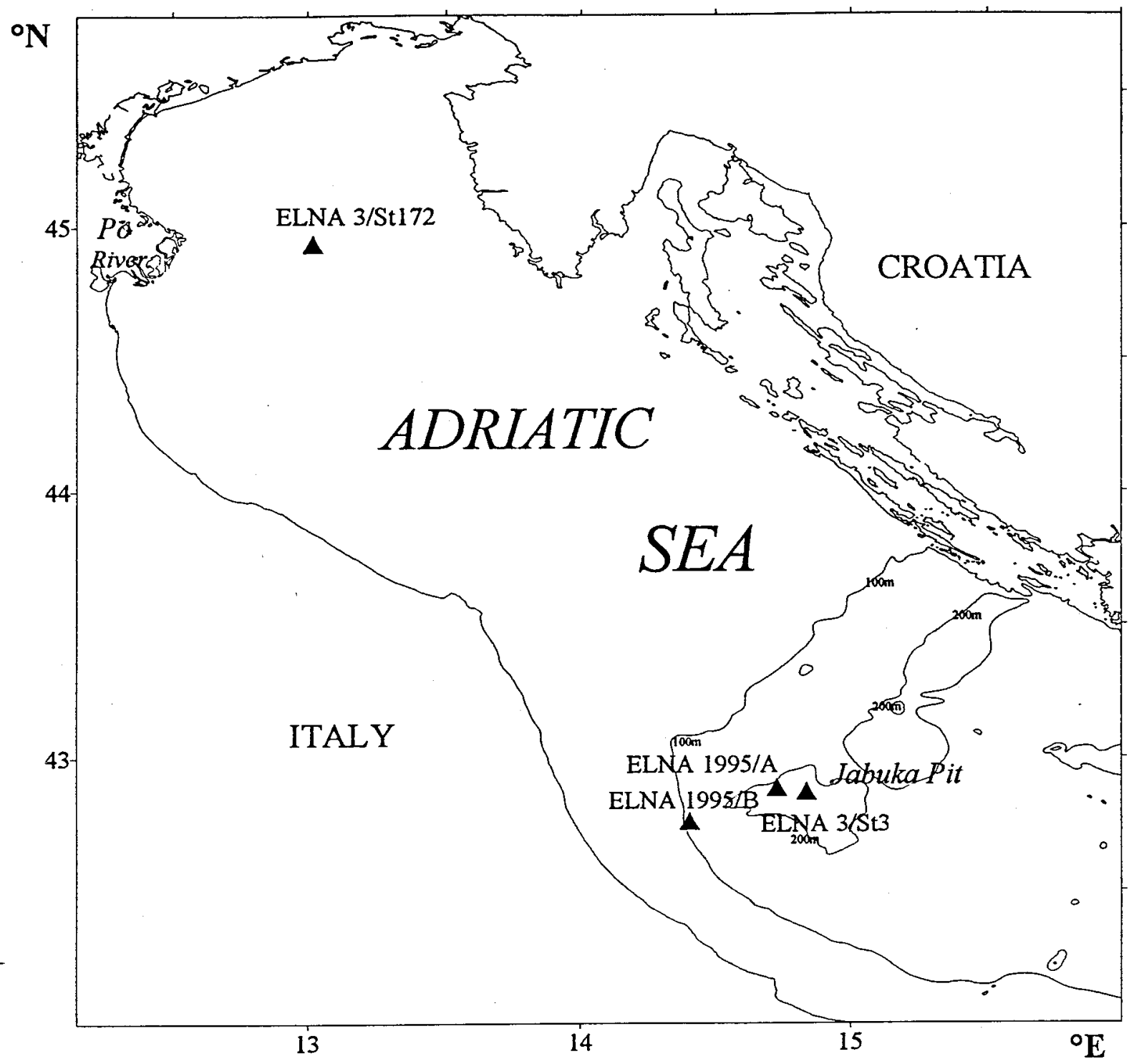

Fig. 1 Geographical area and sample location for drifting sediment trap stations 

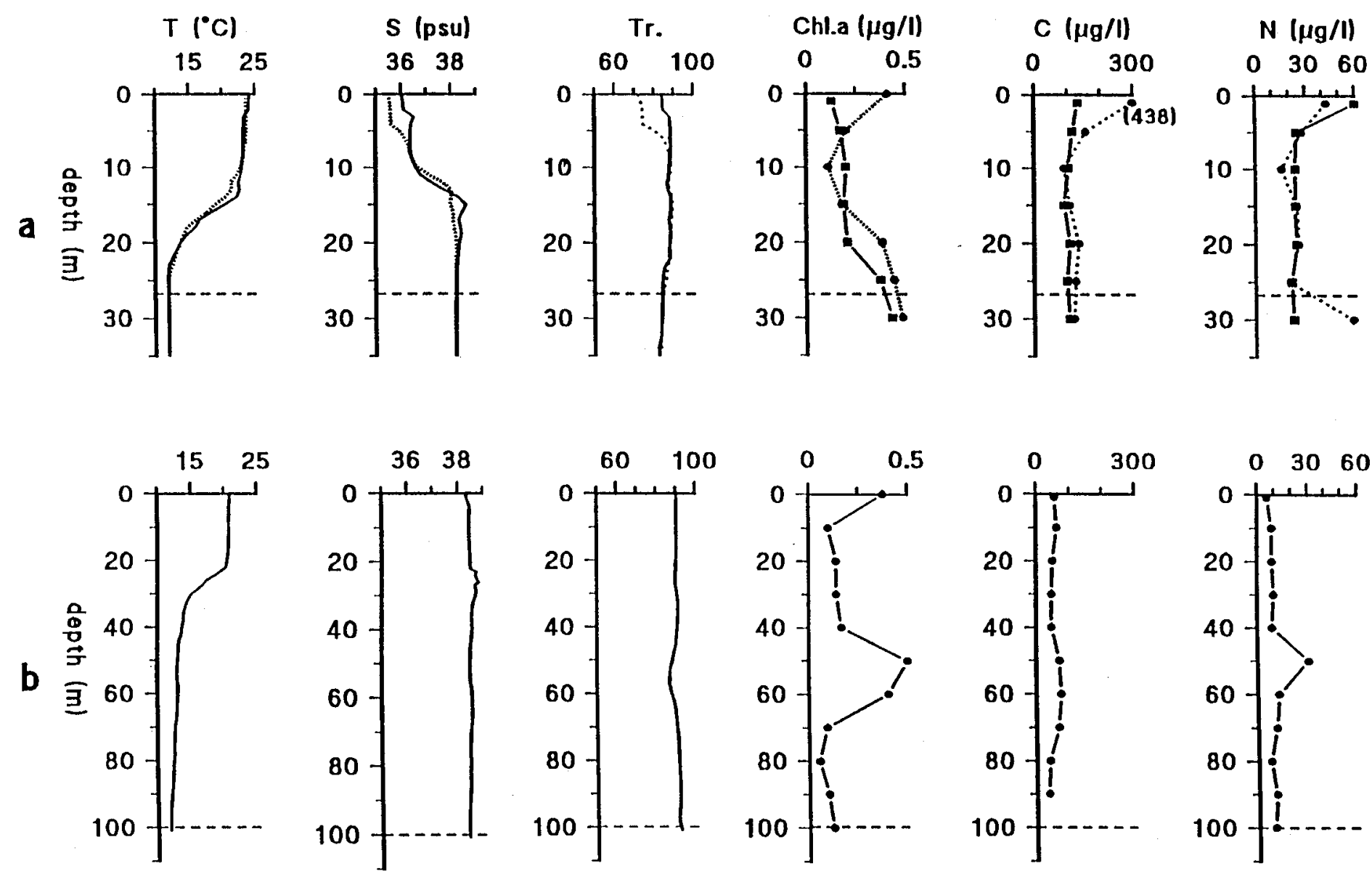

Fig. 2a Vertical profiles of CTD parameters (temperature, salinity, transmissivity), chlorophyll $a$, carbon and nitrogen in the Northern and Middle Adriatic in the vicinity of the sediment traps. Dashed lines indicate the depths of the sediment traps. Note the different $y$-axis scale in (a) and (b).

a: Po outflow, 24 July 1993 (Elna 3, St. 169-171) - b: Jabuka Pit, 14 July 1993 (Elna 3, St. 3) 

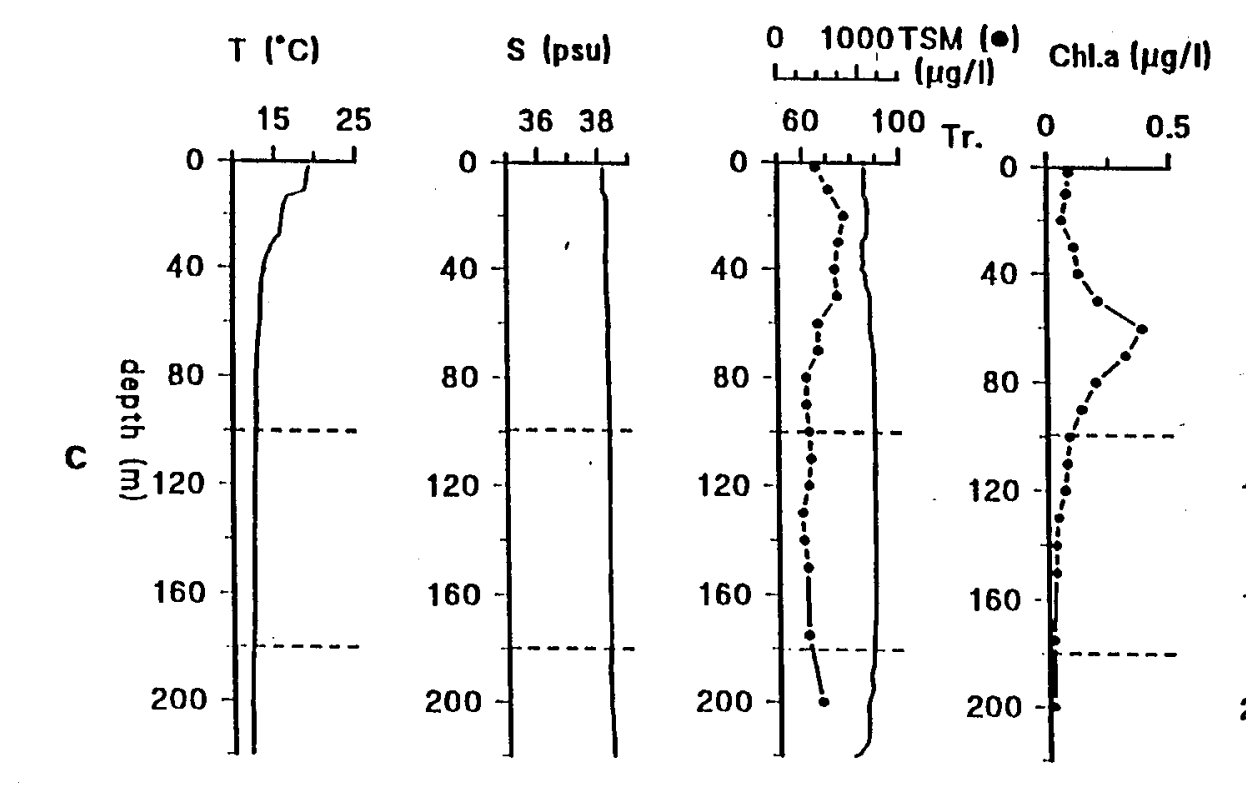

C $(\mu g / 1)$

$N(\mu g / I)$
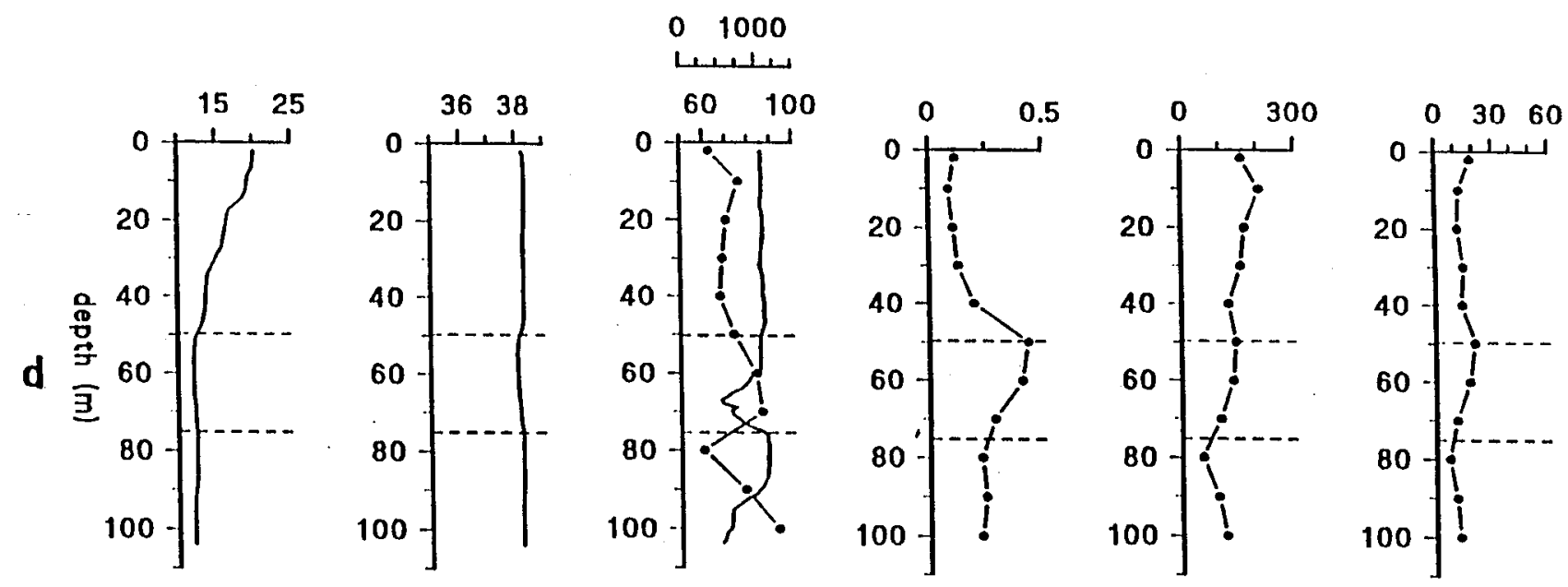

Fig.2b Vertical profiles of CTD parameters (temperature, salinity, transmissivity), total suspended matter, chlorophyll $a$, carbon and nitrogen in the Middle Adriatic in the vicinity of the sediment traps. Dashed lines indicate the depths of the sediment traps. Note the different y-axis scale in (c) and (d). c: Jabuka Pit, 9 June 1995 - d: Central coast near the Giovanna oil platform, 11 June 1995. 


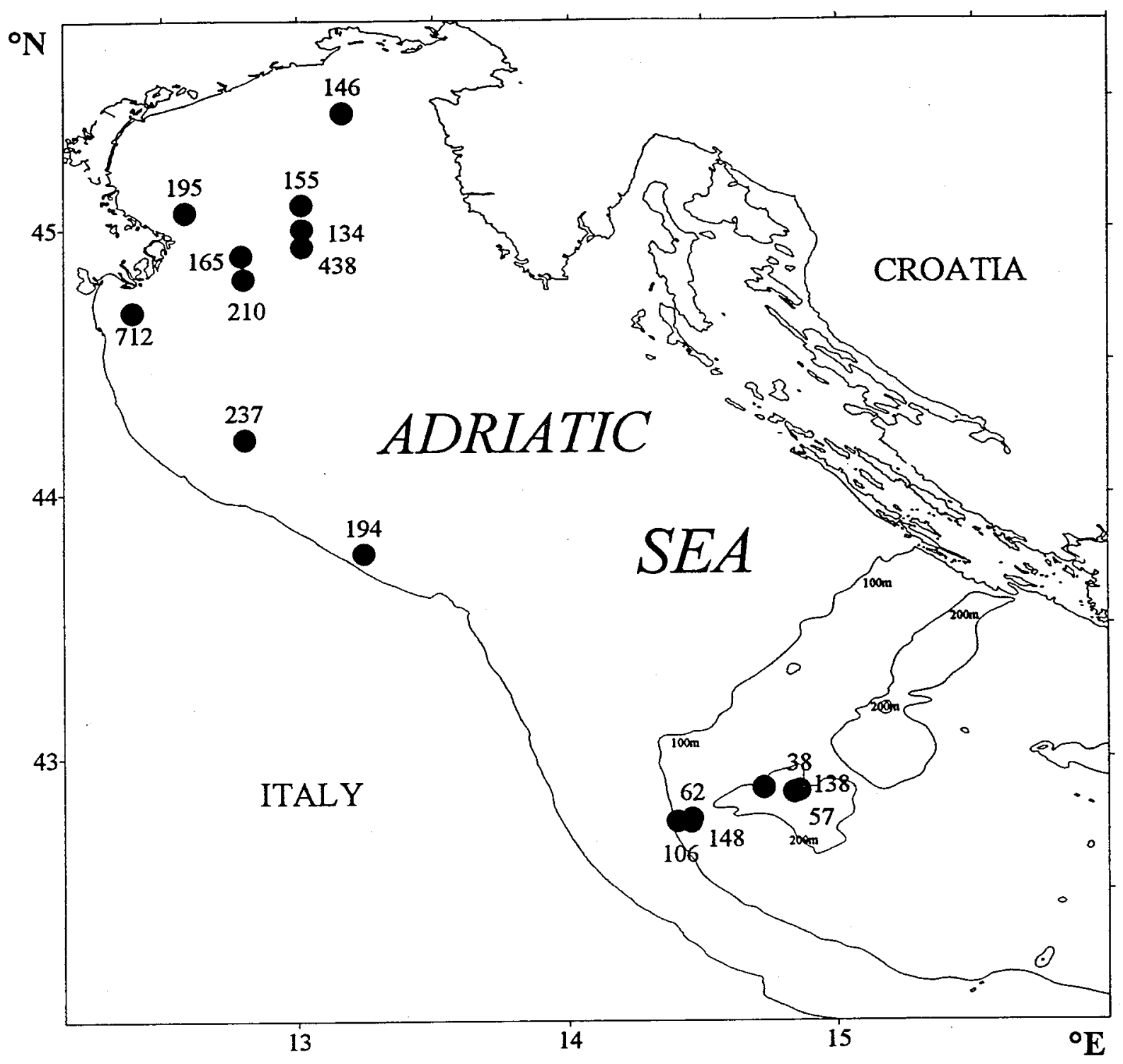

Fig. 3 Particulate carbon concentration $\left(\mu \mathrm{g}^{-1}\right)$ in surface waters in the Northern and Middle Adriatic Sea, 1993-1995 